University of Pennsylvania Carey Law School

Penn Law: Legal Scholarship Repository

Faculty Scholarship at Penn Law

1998

\title{
In Defense of the Model Penal Code: A Reply to Professor Fletcher
}

Paul H. Robinson

University of Pennsylvania Carey Law School

Follow this and additional works at: https://scholarship.law.upenn.edu/faculty_scholarship

Part of the Criminal Law Commons, Legal History Commons, Philosophy of Mind Commons, Public Law and Legal Theory Commons, and the Rule of Law Commons

\section{Repository Citation}

Robinson, Paul H., "In Defense of the Model Penal Code: A Reply to Professor Fletcher" (1998). Faculty Scholarship at Penn Law. 648.

https://scholarship.law.upenn.edu/faculty_scholarship/648

This Response or Comment is brought to you for free and open access by Penn Law: Legal Scholarship Repository. It has been accepted for inclusion in Faculty Scholarship at Penn Law by an authorized administrator of Penn Law: Legal Scholarship Repository. For more information, please contact PennlawIR@law.upenn.edu. 


\title{
In Defense of the Model Penal Code: A Reply to Professor Fletcher
}

\author{
Paul H. Robinson*
}

I. Source and Form
A. The "Missing Fletcher Bits"
B. The Complexity Complaint
C. The Legality Complaint

II. Substance
A. Rejecting the Wisdom of the Common Law and European Law
B. "Imminent Threat" vs. "Immediately Necessary" Response
C. Lesser Evil as a Paradigm for Justifica- tion

III. Criticisms of the Model Penal Code on Which We Agree
A. The Subjective Formulation of Justifica- tions
B. Defining "Elements of an Offense"

IV. Conclusion

I have spent most of my career criticizing the Model Penal Code, so it is with a certain awkwardness that I find myself defending it. The Code has many faults, but not those for which Professor Fletcher condemns it.

Professor Fletcher's objections fall into two categories: objections to the source and form of the Code, and objections to its substance.

\footnotetext{
* Professor of Law, Northwestern University.
} 


\section{SOURCE AND FORM}

\section{A. The "Missing Fletcher Bits"}

Professor Fletcher's most fundamental objectionstated in his Dogma I, but repeated in many other parts of his paper-is that the Code defines concepts that it has no competence to define." "The American Law Institute preempt the role of scholars and theorists by seeking to define concepts better left to philosophical deliberation." ${ }^{2}$ His examples of such betterleft-uncodified doctrines include: (1) the definition of act and the voluntary act requirement (the involuntary act defense), ${ }^{3}(2)$ causation requirements, ${ }^{4}$ and (3) culpability definitions. ${ }^{5}$ Later in his paper he makes the same point as to (4) aspects of defensive force defenses, such as the definition of unlawful force,${ }^{6}$ and (5) aspects of mistake defenses. ${ }^{7}$

Note that this claim is an attack not just on the Model Penal Code but on the idea of a comprehensive criminal code. Professor Fletcher proposes a system in which codes apparently only sketch some of the concepts and rules needed to assess liability. The "missing Fletcher bits," as they might be called, are to be filled in by a decision-maker by reference to the scholarly literature and perhaps, we learn later, by reference to case law and common law doctrine.

My reaction to this "should not define" claim is primarily puzzlement.

First, I wonder, why is it that these provisions, but not others, should be left uncodified? Professor

1. George P. Fletcher, Dogmas of the Model Penal Code, 2 Buff. Crim. L. Rev. 3 (1998).

2. Id. at 11 .

3. Id. at 4.

4. Id. at 5.

5. Id. at 6 .

6. Id. at 8-9.

7. Id. at $17-19$. 
Fletcher says to exclude the definition of causation. Should we also exclude the definition of complicity as well? There are some important conceptual similarities. If we exclude the definition of complicity, should we also exclude the definition of attempt and conspiracy? He says to exclude the definition of culpability requirements. Ought a drafter also be free to omit some objective elements? If we are to exclude the requirement of a voluntary act, as he suggests, why not also exclude the requirements for omission liability? Further, the voluntary act requirement is, of course, the involuntary act defense. Does that mean we also should exclude the conceptually analogous definitions of the insanity defense, the duress defense, and the involuntary intoxication defense? If we are to exciude all of these doctrines, one may conclude that Professor Fletcher simply does not approve of criminal law codification generally. If we are not to exclude all of these doctrines, why not? How are we to tell what is to be included and what excluded in Professor Fletcher's ideal code? He gives us no guiding principle or explanation.

The dramatic effects of Professor Fletcher's approach are illustrated by one of his most vigorously argued proposals, his Dogma VI, in which he insists upon a separate law of mistake defenses, to be developed and controlled by judges. ${ }^{8}$ But to have courts define mistake defenses is to have courts define culpability requirements, for the two are one in the same. For example, to decide that only a reasonable mistake as to an offense element will provide a defense is to decide that negligence as to that element must be proven. To allow an unreasonable mistake in the sense of a negligent mistake to provide a defense is to provide that recklessness is required as to the element; and so on. Is Professor Fletcher proposing that judges define all the instances in which a defendant

8. Id. at 17 . 
may be acquitted for lack of culpability? If so, it would be hard to say we still have a criminal code and legislative definition of offenses. If he intends judges to have authority to define some culpability requirements but not others, what is the allocation of authority between the judges and the legislature? And what is the justification for the division of authority? I can't imagine how or why one might want such a division of authority. Perhaps Professor Fletcher has a theory. If he has, he has not disclosed it.

As to how to determine eligibility to be a "missing Fletcher bit," Professor Fletcher does express a clear preference for omitting from a code those matters on which there is a philosophical dispute. He begins his Dogma I by criticizing the Code for "ventur[ing] precise definitions on matters where many philosophers fear to tread." He then mocks the Code: "Nothing is more controversial than the concept of voluntary action as a precondition of criminal responsibility. But Model Penal Code section 2.01(2) claims it has the answer."

The Code is not in the business of resolving philosophical disputes, of course, as Professor Fletcher seems to fear, but rather in the business of resolving real cases. It needs to tell decision-makers what kinds of cases merit an excuse and which do not, hence the involuntary act conditions listed in Model Penal Code section 2.01(2) ${ }^{11}$ to which Professor Fletcher objects. Similarly, it must define an "act" in order to identify when the special requirements of omission apply. I have much criticized parts of these formulations, but it has never occurred to me that the code drafters were wrong to try to formulate rules of some kind. How else are judges and others to know what rules they are to use? Are the drafters to leave decision-makers with no rule, because to do so might be taken by philosophers

9. Id. at 4 .

10. Id.

11. Model Penal Code $§ 2.01(2)$ (Proposed Official Draft 1962). 
as preferring one side of a debate over another?

More troubling about Professor Fletcher's proposal is the fact that, from my little knowledge of the philosophical literature, I would say one can find conflicting arguments on nearly any point regarding substantive criminal law theory. No doubt Professor Fletcher has clear views on which disputes should be taken seriously and which should not. But not every criminal code drafter can have Professor Fletcher at his or her elbow. Further, other scholars might have a different view from Professor Fletcher's as to which disputes are serious. How is one to determine which philosophical disputes ought to prevent a codification of the disputed issue? We are not told.

But assume Professor Fletcher gives us some operating principles on these matters. I fear I just don't see how the world works under Professor Fletcher's system of intentionally-incomplete-codes. I'm imagining a decision-maker in the criminal justice processa prosecutor deciding what charge to bring, a judge deciding whether to admit evidence or how to instruct a jury. How is the person to determine the rules to apply if not by studying the code? What is the person to do with regard to issues of involuntary acts, causation, culpability requirements, defensive force, or mistake?

For the law to say nothing is to leave the rule to the absolute discretion of the decision-maker. That can't be what Professor Fletcher has in mind. ${ }^{12}$

Perhaps Professor Fletcher has in mind a kind of "Philosophers Full Employment Act." Each prosecutor and judge would consult the criminal code but then

12. I actually do believe that lay persons have good intuitions as to the proper assessment of blame and liability, but I would not want to live in a world where liability judgements in individual cases were subject to the unguided judgments of lay persons. Law can learn much from people's intuitions of justice, but its obligation is to articulate those intuitions in a written form that will apply equally to all. It must be law, not personal intuition, that governs the individual case. I take it that is what we mean by our allegiance to the "rule of law." 
fill in the "missing Fletcher bits" by consulting his or her resident philosopher. That sounds expensive. It might be cheaper just to send them all to university for PhDs in philosophy or, if that to is too expensive, perhaps just a Masters. They will remain amateur philosophers, of course-they will be unfortunately diverted from their continuing philosophical study and reflection by their law job-but we could retain a kind of supreme council of professional philosophers for harder questions. I'm assuming here that Professor Fletcher would not approve of the idea of persons unschooled in philosophy being relied upon to properly interpret and apply the philosophical literature, for that would be no better than letting the unschooled criminal code drafters interpret and apply the philosophical literature.

It's hard to see what advantage is offered by Professor Fletcher's system of an intentionally incomplete criminal code. Yet, its vices are all too clear: it undercuts all of the reasons for which we adhere to the principle of legality: (1) by having some aspects of the governing rules imbedded somewhere in the philosophical literature, the law puts out of reach fair notice to the lay person governed by that law. By requiring a decision-maker to exercise discretion in formulating the governing rule, based upon his or her reading of the literature, the law invites all of the vices inherent in discretion: (2) It increases the potential for abuse. (3) Even among officials acting in good faith, it increases the chances of disparate treatment of similar defendants as different officials read the literature differently. (4) It reduces the predictability of law, and thereby undercuts the stability that the rule of law seeks to bring. (5) It also shifts criminal law-making authority away from the legislature, the most democratic branch, to unelected and unaccountable scholars. Scholars and philosophers have much to teach criminal code drafters, but our commitment to legality prevents them from being of- 
fered as a substitute for a criminal code, as Professor Fletcher wishes.

These administrative and legality problems with Professor Fletcher's system are made all the worse by his special preference for deferring to the literature on issues of ongoing philosophical dispute. Where the literature expresses different views, the decision-maker necessarily is forced to decide which of the conflicting views to follow. This will pretty much guarantee different conclusions by different decision-makers. The result in any given case, then, will depend on what judge the defendant gets, not on the defendant's blameworthiness. That can't be the result that Professor Fletcher wants.

But inconsistency in application is only part of the problem for Professor Fletcher's system. The peculiar effect of his scheme is to require the philosophically least competent and least trained, the working prosecutors and judges, to make the ultimate decision between conflicting philosophical/scholarly positions. How is that better than having criminal code drafters, such as the law professors of the American Law Institute, make those decisions? Even if code drafters were as philosophically weak as the local magistrate, their decisions at least have the virtue of being consistently applied in similar cases. ${ }^{13}$

Professor Fletcher might argue that over time appellate judges reading the scholarly literature would decide the issues and that this would increase uniformity and predictability. But, again, one may ask why Professor Fletcher has so much greater faith in appellate judges than criminal code drafters? If appellate judges are so much better makers of criminal law, why did the Americal Law Institute face what everyone seems to agree was an unmitigated mess when it undertook to review American criminal law? But even

13. No doubt Professor Fletcher has clear views on how the disputes in the literature should be resolved. But, again, not every prosecutor and judge can have Professor Fletcher at his or her elbow. 
if one assumes that appellate judges could read the literature as well as code drafters, the case law that they generate can never provide the legality advantages that a written code provides. That is, it is less able to provide people with fair notice, less able to provide uniformity and predictability (and certainly is less a product of democratic decision-making).

I have focused so far on Professor Fletcher's apparent preference for law-making by scholars and judges and opposition to law-making by code drafters. But there is some indication that Professor Fletcher objects to more than who is making the law. Even if there were a scholarly consensus on the best rule to follow and its articulation, Professor Fletcher still might prefer to keep that rule in the literature and out of the code. He cites with approval the German Code's failure to define the meaning of "unlawful force" in defensive force defenses, noting that "any german textbook" ${ }^{\prime 14}$ will provide a definition.

Again, I'm puzzled. What could be the benefit of keeping some aspect of the rules governing liability out of the criminal code? To do so can only reduce the possibility of fair notice to citizens and increase the possibility of discretion by officials as they decide what meaning to give the undefined term or how to formulate the uncodified rule. One could minimize these problems by having the code authoritatively say something like: the phrase "unlawful force" has the meaning given at page $x x$ of textbook yy. But if the code is to go that far, then why not simply include the definition within the code? I don't get it.

14. Fletcher, supra note 1 , at 8 .

15. As to Professor Fletcher's proposal that judges define offense culpability requirements, for example, I ask the same questions: What is the evidence that judges would do a better job of defining culpability requirements than criminal code drafters like those of the American Law Institute? Witness the pre-Model Penal Code mess. And, what are the advantages of excluding a statement of offense culpability requirements from the code?

One can certainly make arguments for how code culpability defi- 
One more point before we depart from Professor Fletcher's preference for leaving some concepts and rules undefined in the code. The unarticulated assumption of his analysis is that each of the concepts or rules he wants undefined in the code has some natural, intrinsic meaning of its own, a meaning that philosophers are working to discover and explicate. That assumption may be correct if one is a retributivist, as Professor Fletcher appears to be. ${ }^{16}$ But it is not necessarily correct if one is not. Under a utilitarian approach, the proper definition of a concept or formulation of a rule may depend on the particular conditions within the criminal justice system and society at the time.

But assume, for the sake of argument, that Professor Fletcher is right to press a retributivist view. I fear that his proposed intentionally-incomplete-code will not further the retributivist goal he assumes it will. The fact is, many (if not most) judges and criminal law scholars in current America do not share Professor Fletcher's retributivist views. If they are given the power to fill in the "missing Fletcher bits," they will look for guidance not to the philosophical literature, but to other places, probably the economic litera-

nitions might be improved, but it can only undercut the virtues of legality to permanently condemn culpability requirements to existence only in the case law. To learn the culpability requirements of an offense, one would have to wait until such requirements were developed case by case by judges. Even after the common law process was complete (would it ever be?), one could learn the culpability requirements of an offense only by studying the cases that addressed the subject. What are the benefits that would justify this dramatic reduction in the notice, uniformity, and predictability?

I would argue that we ought to move in the exact opposite direction. We ought to reform the Model Penal Code's scheme for defining offense culpability requirements to avoid the occasional ambiguities that have been revealed in the 36 years since its promulgation.

16. I happen to support Professor Fletcher's preference for a desert distribution of liability, but many others will not share this view. But I would rely on consequentialist as well as his retributivist reasons. See generally Paul H. Robinson \& John M. Darley, The Utility of Desert, 91 Nw. U.L. Rev, 453 (1997). 
ture. I think Professor Fletcher will not be happy with the results that this will bring.

\section{B. The Complexity Complaint}

Moving on to Professor Fletcher's other points regarding form and source, in his Dogma II, Professor Fletcher objects to some Model Penal Code provisions as too complex, such as the culpability definitions. My initial reaction is to simply disagree that these provisions are too complex. ${ }^{17}$ My first year, first term law students master them quickly. Why not judges and instructed jurors? Could they be improved upon and simplified further? Probably.

But Professor Fletcher's other complaints against the Code suggest that I should make a different response here. His earlier claim that we ought to defer to the scholarly literature and the case law surely throws the decision-maker into greater complexity than anything Professor Fletcher can cite in the Model Penal Code, including the culpability definitions. If complexity for decision-makers is a legitimate concern, how can he argue that they should consult the philosophical literature to divine the liability rules?

Indeed, every distinction contained in the Model Penal Code no doubt appears in one case or another and one scholarly article or another. Under Professor Fletcher's intentionally-incomplete code, the decisionmaker must sort through these articles and cases, decide which distinctions ought to be used and which ignored, then synthesize the useful distinctions into a rule to be applied in the case. Every judge a criminal code drafter. How can Professor Fletcher's system of reading the literature be less complex than judges reading a Model Penal Code provision and its official commentary? Compared to the tortuous arguments one easily finds throughout the scholarly literature,

17. Fleicher, supra note 1 , at 8. 
the Model Penal Code provisions look downright pedestrian.

I agree that complexity is to be avoided as much as possible. And I have suggested in print ways of reducing it and of limiting its detrimental effects (e.g., by requiring greater simplicity in rules of conduct, which the average citizens must be able to apply quickly, than is required in principles of adjudication, which are applied by trained persons under more thoughtful conditions). ${ }^{18}$ But in the end, the proper distribution of liability sometimes depends upon a concept that is complex. Offense culpability requirements are a good example. The law must be as complicated as are our notions of justice.

\section{The Legality Complaint}

Professor Fletcher offers one final objection as to form: what he says is the Code's failure to take legality seriously. In his Dogma IV, he cites the fact that the Code allows not only statutory duties but also common law duties as the basis for omission liability. ${ }^{19}$ He says, "The Model Penal Code makes a strong commitment to the principle nulla poena sine lege in $1.05(1) \ldots$. Would that it were so."

I was astonished to read this. Had he not just finished explaining at length his preference for an incomplete code, for judicial law-making, for requiring judges to consult the scholarly literature to divine the governing rule? How can the Code's cross-reference here to the case law in its ommission provision be offensive to him? Given what he has said previously, I would have thought he would conclude the Code drafters here had finally gotten it right.

Not so. Rather than being concerned that his le-

18. See, e.g., Paul H. Robinson, Structure and Function in Criminal Law, Part IV (1997)

19. Fletcher, supra note 1, at 11-12.

20. Id. at 11 . 
gality complaint might make him appear hypocritica he attacks. He is indignant: "Even if we [American: continue to violate the [rule-of-law] principles we pu port to endorse, we should at least be forthright abou what we are doing." ${ }^{21}$ Perhaps the best defense is good offense.

I happen to believe that the Code should limi criminal liability for omissions to a failure the perform a statutory duty. But I think Professor Fletcher ma: have forfeited his right to join in this complaint.

These, then, are Professor Fletcher's objections t, source and form. He also has objections to the sub stance of many specific Model Penal Code provisions.

\section{Substance}

In his objection to the code defining concepts that it is incompetent to define ${ }^{22}$-his Dogma I-Professor Fletcher implicitly criticizes the Code's formulations in the examples he gives: the voluntary act requirement, the causation requirements, and the culpability definitions. Presumably he prefers different definitions, given somewhere in the scholarly literature. But if he has some better formulations to suggest, he does not offer them.

I have quibbles with the Code's approach on each of these issues. But I also see much to defend in each provision. And each is surely better than the law adrift, with no articulated rule, which was typical before the Model Penal Code, and seems to be that to which Professor Fletcher wants to return.

\section{A. Rejecting the Wisdom of the Common Law and
European Law}

A recurring theme of Professor Fletcher's objec-

21. Id. at 12

22. Id. at 4. 
tions is that the Code ignores the wisdom of European law, as well as the wisdom of our own common law history, an objection explicitly stated in his Dogma III. ${ }^{23}$ He cites as examples the Code's culpability definitions, its shift from provocation to extreme emotional disturbance, and its dropping of the larcenyembezzlement distinction. ${ }^{24}$

$\mathrm{He}$ is accurate in his description of these doctrines as changes from common law, but he fails to explain why these changes are bad. Can he be claiming that every change from the common law is objectionable? If not, what is there about these particular changes, one might wonder, that he finds objectionable? I think I'm prepared to defend the provisions he cites as advances over common law, but perhaps he has arguments to the contrary.

As to Professor Fletcher's general complaint that the Code lacks adequate deference to common law, I find him being somewhat inconsistent. In his Dogma VII, he castigates the Model Penal Code for adhering too closely to the common law rule that mistake or ignorance of law is no excuse. ${ }^{25}$ The Code provides a general mistake of law defense that the common law did not, but this does not go far enough, Professor Fletcher complains. The drafters should have gone all the way, to recognize an unlimited reasonable mistake of law excuse. ${ }^{26}$

But one may wonder how the drafters' lack of deference to the common law in other instances shows an insensitivity to its wisdom, yet they are to be condemned here for not straying farther from it. I believe the Model Penal Code is wrong not to break entirely from the common law on this point. (It ought to recognize a general excuse of reasonable mistake of law, but put the burden of proof on the defendant). But,

23. Id. at 10 .

24. Id. at $10-11$.

25. Id. at $21-22$.

26. Id. at 24 . 
again, by his earlier complaints, Professor Fletcher may have forfeited his right to join in this criticism of the Code.

In the end one must conclude that Professor Fletcher's selective insistence on deferring to European law or common law is simply an expression of his own personal objections to one Code provision or another: the Model Penal Code drafters should have deferred when Professor Fletcher approves of the common law or European provision, but not when he doesn't. If Professor Fletcher has specific objections to the Code, a better approach would be to offer them on their merits. I see little reason to think that the pedigree of a rule ought to matter in our analysis of it.

\section{B. "Imminent Threat" vs. "Immediately Necessary" Response}

The force of the pedigree point becomes apparent when Professor Fletcher actually states his objections to some Code provisions that he claims ignore available wisdom. In Dogma V, he criticizes the Code's shift from the common law's "imminent threat" requirement to trigger a right of defensive force, to an "immediately necessary" response requirement. ${ }^{27}$ Professor Fletcher does not like the change. But, in my view, it is a welcome improvement over the flawed common law rule. If an actor must wait until an expected threat is actually imminent, it may be too late to successfully defend. If the crew on a sinking ship must wait until the ship is about to sink before they take charge from an unbalanced captain, it may be too late to act. If they are two days from land and the ship will sink in two days, their present use of force is then "immediately necessary" and ought to be allowed, even if the threat of sinking is not "imminent." That the "imminent threat" requirement is a common law

27. Id. at 15 . 
doctrine only suggests to me that common law rules can be flawed and can be improved.

\section{Lesser Evil as a Paradigm for Justification}

To give another example, in Dogma V Professor Fletcher objects to the use of the lesser evils defense as the paradigm for justification defenses. ${ }^{28}$ It is not a proper paradigm for self-defense, Professor Fletcher complains, because in self-defense the conflicting harms are equal-a life for a life-and the notion of balancing to avoid the lesser evil has no application. But his objection only suggests that he may be misinterpreting the Code's lesser evils provision. He apparently takes it to require a balance only of threatened physical harms. But clearly that cannot be right. Much of criminal law prohibits conduct that involves intangible harm and evil, and harms to societal rather than private interests. I take this to be the point of the lesser evil provision's reference to the "harm or evil" ${ }^{\text {"9 }}$ of the offense, to make explicit its broad focus on more than just physical "harm." Consider the variety of offenses that prohibit other than a "harm": fraud, obstruction of justice, adult incest, bribery. When section 3.02 directs a balance between "the harm or evil ... of the offense charged" and "the harm or evil sought to be avoided," ${ }^{30}$ it seems clearly to refer to more than the tangible bodily harms that Professor Fletcher envisions.

When one looks at the lesser evils in this light-as providing a balance of all competing interests, tangible or intangible, societal or personal-it is easy to see it as a paradigm for justification defenses, including self-defense. Yes, a life is at stake on each side of the balance in self-defense, but also at stake is society's abhorrence of unjustified aggression. Indeed, it is this

28. Id. at 13 .

29. Model Penal Code $\S 3.02$.

30. Id. $\S 3.02(1)(\mathrm{a})$. 
intangible interest that is determinative; it tips the scale in favor of the offender and against the unjustified aggressor. In my view, the Code drafters' treatment of lesser evils as a paradigm for justifications is an important conceptual advance-and I note that it was an advance for which the then-existing American scholarly legal literature provided little or no help.

\section{Criticisms of the Model Penal Code on Which WE AGREE}

I do not want to leave the impression that I disagree with all the Code criticisms that Professor Fletcher offers. I have already said I agree the Code should recognize a general reasonable mistake of law defense (although I would put the burden of persuasion for this on the defendant). I have also agreed that the Code should limit omission liability to violation of a statutory duty.

\section{A. The Subjective Formulation of Justifications}

Further, I very much agree with Professor Fletcher that the Code is misguided in its subjective formulation of justification, in which it treats conduct as "justified" if the actor mistakenly "believes" it to be justified. It is because of this error that the Code is forced into its pitiful definition of the "unlawful force" that triggers a right of defensive force. By defining "justified" conduct as conduct that the actor "believes" is justified, the Code has contaminated its term "justified"; it has packed both objectively justified conduct and mistaken justification into the single term. But it then must unpack these two kinds of cases when it seeks to define the force that lawfully may be resisted: an actor may resist mistaken justification but may not resist actual, objective justification. Interestingly, the Code's error here may well have been the result of ill-advised reliance upon the philosophy 
literature, for that literature offers support for using the term "justified" in a subjective sense. ${ }^{31}$ How can Professor Fletcher have such faith in deferring to the scholarly literature for enlightenment when it produces results with which he so much disapproves?

\section{B. Defining "Elements of an Offense"}

I also agree with Professor Fletcher that the Code is wrong in section 1.13(9) to define "elements of an offense" to include the absence of most general defenses. ${ }^{32}$ I think the drafters' silliness here was simply a too-clever-by-half attempt to push states to allocate the burden of persuasion to the state to disprove most defenses. Note that this definition appears in the section immediately following that in which the drafters provide that the state has the burden of persuasion on all "elements of an offense." ${ }^{\text {"3 }}$ Whatever one may think is the proper allocation of the burden of persuasion on defenses, it is clearly asking for trouble to define "element of an offense" to include defenses, in a definition that, by its terms, applies not just to the preceding section on burden of proof but to the entire Code.

When I see this drafting error, I see just that: an obvious drafting error. I see little evidence that it ever occurred to the drafters that the section 1.13 definition would be taken to apply to section 2.04(1), which gives a defense for a mistake that negates "an element of an offense. ${ }^{, 34}$ By assuming that the definition is meant to apply through section 2.04(1) to defenses, Professor Fletcher beats a straw man. Who would think it makes sense to give a defense because a defendant's mistake negates the requirements of a de-

31. See the philosophical sources cited by Kent Greenawalt in his article, The Perplexing Borders of Justification and Excuse, 84 Colum. L. Rev. 1897 (1984).

32. Model Penal Code $\S 1.13(9)$.

33. Id. § 1.12.

34. Id. $§ 2.04(1)$. 
fense? On the contrary, one must satisfy the requirements of a defense, including its culpability requirements, to get the defense. One can only laugh that this one got by the drafters, probably because a different group drafted the Article 1 provisions than drafted the general defenses in Articles 2 and 3. In fact, the general defense drafters provided specific provisions governing the treatment of mistake as to a defense, as in section 3.09. ${ }^{35}$

Yet, Professor Fletcher takes the Article 1 drafters at their written word, applies the mistake defense in section 2.04 to defenses, and shows the absurd results. $\mathrm{He}$ is right. The Code drafters erred. Let's shoot them. But it is hard to see that the error says something larger about the Code or code drafting. What it says to me is that the first people who try to produce a comprehensive code, with little to build on, will do an imperfect job.

If the error illustrates a larger point, it is this: one of the great benefits of a comprehensive code is that it effectively reveals the shortcomings of its formulations. The rambling paragraphs of case opinions and scholarly literature, in contrast, provide a permanent haven for the murky rule. Leaving the law's rules to the shadows of case law and scholarly literature, where there is never a clear target, means less likelihood of seeing and correcting law's flaws. It is only when one proposes a specific code formulation, which all can see and understand, that flaws become easy to see, criticize, and reform. This process-of formulation, criticism, and reform-is the path to a better criminal law, while maintaining the virtues of legality
throughout.

\section{CONClusion}

Professor Fletcher and I do agree on who is to

35. Id. $§ 3.09$. 
blame for the current weakness in American criminal law. Given the abysmal state of American criminal law and theory that faced the Model Penal Code drafters, their Code was dramatically better than anyone had a right to expect. They brought us a quantum leap forward. Our current messy state is in large part our own fault, that of current American criminal law scholars. We have failed to build upon and refine the sound foundation the Model Penal Code provided us. We have failed to systematically study, criticize, and propose reforms to the Code.

The American Law Institute must share in the fault. Criminal law scholars have offered some criticisms of the Code-enough to make it clear that it needs reform-yet, the American Law Institute has refused to undertake a revision. An individual state's law makers cannot substitute in this role; they have neither the resources nor the talent that the American Law Institute has. In promulgating a Model Penal Code, the American Law Institute sought and obtained the trust and reliance of many states who adopted their model code. Knowing the model to be seriously flawed, the Institute has an obligation to address those flaws. 